\title{
Mariusz Wojewoda
}

University of Silesia, Katowice, Poland

(D) https://orcid.org/0000-0003-0732-7500

\section{Karol Wojtyłass Conception of Personhood from the Perspective of Cognitive Sciences}

\begin{abstract}
We use the term "person" when we want to point out that human existence is unrepeatable and unique. The assumption that man is a person constitutes a basis for the belief in the dignity, efficacy, and responsibility of the human individual. Karol Wojtyla built his conception of the person in the context of theological and philosophical discussions. Even though Wojtyła's conception has been given a great deal of scholarly attention, it is worthwhile to juxtapose it with contemporary anthropological theories that derive from cognitive sciences. Cognitivists usually base their theories on biological and sociological premises. Some conclusions arrived at in the area of the cognitive sciences lead to mindbrain reductionism, a theory in which the human being is regarded as a body endowed with the function of the brain and as an entity whose individual traits are shaped by its social and cultural environment. This position undermines the ideas of free will and the substantial singularity of the human person. However, debates with this position have worked out a non-reductionist alternative, a theory known as emergentism. This theory treats the human mind as a distinct faculty, one which emerges as a phase in the brain's development. Emergentists base their reasoning on the assumptions that the body is a unity and that the mind is not identical with it. It is my belief that emergentism can be fruitfully applied to the dynamic understanding of the person put forward by Wojtyła in the middle of the 20 th century.
\end{abstract}

Keywords: Karol Wojtyła, person, human nature, free will, cognitive sciences 


\section{Introduction}

The idea of personhood has ontological and ethical aspects, such as: (1) the concept of the person points to the unique character of human existence in the world; (2) it underscores the individual aspect of human experience; (3) it emphasises the wholeness of the person, which, in the traditional formulation, is a unity of body and soul; (4) it points to the necessity of showing the respect that is due to every human being; the person ought not to be treated instrumentally, as a means to a goal, but always as a goal in itself. These aspects allow us to link other ideas to that of "the person," such as that of "personal dignity"; and then, too, we point to the special value of the person in relation to the real world of things as well as to social and political institutions.

The idea of "the person" is defined in a number of ways, and it is not my aim in this article to discuss these definitions, but to present the tension between the personalist and cognitivist outlook on man. The recognition of the value of the human person is inherent as a basic principle in Western culture, which is built on a grid of concepts derived from Greek philosophy and made permanent by Christian thought. The distinctness of the human person is, in this respect, to be regarded in a normative sense. This by no means ought to prevent us from using the idea of personhood in the context of Eastern cultures. According to anthropologists, in the East it is common to believe in a strong interdependence between an individual and the community within which he or she functions. Assumptions concerning an individual person's relations with a community constitute a point of departure for cultural studies and also, recently, for cultural neuroscience, which combines the methods of social and cultural psychology. ${ }^{1}$ Yet this problem falls beyond the remit of this article.

Cognitivism is a relatively new discipline which combines various areas of knowledge concerned with the principles of the functioning of the brain in relation to the body, as well as to the natural and human environment. The different subdisciplines of cognitivism derive from a number of particular sciences: from formal ones like logic, mathematics, information technology through natural sciences, such as biology; social sciences, such as psychology2; and from the humanities, such as philosophy. This manner of combining subdisciplines does

${ }^{1}$ See Shihiu Han, Georg Northoff, Kai Vogeley, Bruce E. Wexler, Shinobu Kitayama, and Michael E. W. Varnum, "A Cultural Neuroscience Approach to the Biosocial Nature of the Humane Brain," Annual Review of Psychology, vol. 64, (2013), https://doi.org/10.1146/annurevpsych-071112-054629. The article contains a copious list of publications concerned with cultural neuroscience.

${ }^{2}$ See Urszula Żegleń, "Znaczenie filozofii dla kognitywistyki [The Meaning of Philosophy for Cognitivism]," in: Przewodnik po kognitywistyce [Cognitivism: A Guidebook] ed. Józef Bremer (Kraków: Wydawnictwo WAM, 2016), 39-78. 
not prevent collisions, as demonstrated, for instance, by all the diverse ways of understanding human nature. In recent years, cognitive science has drawn ever closer to neuroscience-including neurobiology — which studies the anatomy and physiology of the brain. Cognitivism may belong among the humanities and social sciences, and yet cognitivists readily employ empirical research and computer-assisted imaging techniques (MRI, FMRI, PET, and others). Emerging from a combination of different disciplines and the conceptions they have developed, cognitivism has not yet produced a central, unifying theory. In a narrower sense, the goal of cognitivism is to analyze man's cognitive abilities and to examine the conditions necessary for their operation; in a broader sense, its goal is to describe and explain the principles of cognition in living organisms, and to define the rules determining the acquisition of the knowledge of the surrounding physical world and of the knowing subject, on the basis of empirical research. Cognitivist anthropology, which studies biological systems and the influence of artificial intelligence on human life, is distinguished from cognitive anthropology, which has for its object the rules that govern the ways in which culture influences the human brain. The latter discipline studies language, cultural narratives, interpersonal relations, and man's conduct as a social being. ${ }^{3}$ Polish researchers who work within the field of cognitive anthropology have taken up the topic of personhood in several substantial studies and texts. ${ }^{4}$

In this article I undertake an analysis of Karol Wojtyła's conception of personhood, which I want to juxtapose with the cognitive view on man. Wojtyła's main work in the field of human anthropology, The Acting Person (In Polish known as Osoba i czyn), was written in the late 1960s; it has since been a subject of creative interpretations and polemics. Wojtyła's tract is devoted to man and to man's relation to his biological and social environment. As far as his method is concerned, Wojtyła uses two basic sources: (1) the tradition of Thomistic realism: the thought of St. Thomas Aquinas and his 20th-century interpreters, Reginald Gerrigou-Lagrange, Etienne Gilson, Stefan Świeżawski, and oth-

${ }^{3}$ See Roy D'Andradde, The Development of Cognitive Anthropology (Cambridge, UK: Cambridge University Press, 1995 ), XIV-XV.

${ }^{4}$ See Józef Bremer, Osoba - fikcja czy rzeczywistość [Person - Fiction or Reality]/ (Kraków: Wydawnictwo WAM, 2008); Józef Bremer, Neoronaukowcy i potoczny obraz osoby w kognitywistyce [Neuroscientists and the Common Image of the Person in Cognitivism]. (Kraków: Wydawnictwo WAM, 2016); Józef Bremer, Problem osoby w świetle neuronauk. Czy osoba to jedynie uzyteczna metafora? [The Problem of Personhood in Light of Neurosciences: Is the Person Anything But a Useful Metaphor?]. STD, nr 4 (2018), https://doi.org/10.15290/std., 11-27. Włodzisław Duch wrote in a slightly different sense about the issues and responsibility in the context of cognitive research See: Włodzisław Duch, "Czy jesteśmy automatami? Mózgi, wolna wola i odpowiedzialność" [Are We Automatons? Brains, Free Will and Responsibility?], in Na ścieżkach neuronauki [On the Paths of Neuroscience], ed. Piotr Francuz (Lublin: Wydawnictwo KUL, 2010), 219-264. 
ers; (2) phenomenology, known from his study of the thought of Maks Scheler, ${ }^{5}$ in Wojtyła's critical reinterpretation. The moral philosophy of Immanuel Kant was also a major inspiration for Wojtyła's ethical deliberations. My aim in this article is to focus on those aspects of Wojtyła's conception of personhood which allow it to enter into dialogue with the conception of man accepted by chosen cognitivists. ${ }^{6}$

\section{Nature and the Person}

Wojtyła's conception of personhood is based on three types of premises: metaphysical, religious, and cultural. As it would be difficult to discuss all the aspects of The Acting Person in this article, I have decided to focus on the following elements: human nature, the dynamics of becoming a person, the psychosomatic unity of the soul and the body, and personal freedom.

Human nature can be understood in three different ways: (1) as a substance: the nature in question determines the belonging of an entity to a species; possessing a nature means that a person differs from other entities (animals, plants, and inanimate beings, all of which are deprived of the feature of rationality); (2) normatively: possessing a particular nature means that man has to perform particular tasks; it defines obligations (which determine what man ought to do due to the good that is in accord with human nature). Normative understanding also delineates limitations for human actions, the violation of which entails the infringement of an essential good; (3) as an entity belonging to nature: as when we point out that the human being possesses a body and belongs to the sensory realm. The term "to possess" refers to a relational situation, which means that there is in us something that controls the operation of the body. Here clearly appears the suggestion that outside the body, there is a decision-making center that controls the body, that is, the soul or the mind.

In medieval philosophy, to which Wojtyła is indebted in the context of the problem of personhood, a major role was played by the principle of individuali-

${ }^{5}$ Karol Wojtyła, Ocena możliwości zbudowania etyki chrześcijańskiej przy założeniach systemu Maksa Schelera [An Appraisal of the Possibility of Building Christian Ethics on the Principles of Maks Scheler's System], in Człowiek i moralność II: Zagadnienie podmiotu moralności [Man and Morality II: The Problem of the Moral Subject], ed. Tadeusz Styczeń, Jerzy W. Gałkowski, Adam Rodziński, and Andrzej Szostek (Lublin: TN KUL), 11-129.

${ }^{6}$ In the linguistic context, the author of this article refered to a text by Jameson Taylor, "Beyond Nature: Karol Wojtyla's Development of the Traditional Definition of Personhood." The Review of Metaphisics, vol. 63, no. 2 (2009): 415-454. Taylor cites and analyzes extensively from Wojtyła's book The Acting Person. 
zation, that is, the problem of to what we owe the fact that we are distinct entities. This is the principle thanks to which a person acquires his or her individuality. It follows from Boethius's classic definition according to which the person is "an individual substance of a rational nature" (persona est naturae rationalis individua substantia). ${ }^{7}$ In order to be a person, a being needs to be a rational entity, a substance made up of matter and form. "Person" is not a general designation but refers to an entity that exists in reality. Boethius's definition captures the essence of personhood in a static manner, while the contemporary ways to understand human nature underscore the dynamics of becoming a person. This makes Wojtyła's conception relevant.

The aspect of a person's individual existence was of interest to, among other philosophers, Thomas Aquinas and John Duns Scotus. Thomas defined the person as the thing, in all of the natural world, that is the most perfect (persona significat id quod est perfectissimum in tota rerum natura). In this sense, the wholeness and uniqueness of a person consists in its being a value which must not be modified or changed. In order to protect the entirety of a person's existence, no constituent part of the person should be altered. In Thomas Aquinas's anthropology, the human soul is not a complete dimension of the person; it is the body that endows a person with the particularity of individual existence. The human being is an inseparable unity of the soul and the body, a unity of elements which together form the whole that is the compositum humanum. ${ }^{8}$ John Duns Scotus wrote about the principle of individualization in a different sense. He used the untranslatable term haecceitas, which refers, not to matter, but to the essence which endows an entity with individuality, bestowing distinct properties on things and people, and thus rendering them singular. Haecceitas influences the properties that belong to and determine an individual entity and it is thanks to haecceitas that a human being has the features of indivisibility, identity, actuality, and singularity. A multiplication of individuals representing the same species means greater perfection in the world, as different from a multiplication of the species as such. ${ }^{9}$

One of the consequences following from the thought of John Duns Scotus is the linking of the individual person with the soul (the mind) rather than the body, as is the case in the philosophy of Thomas Aquinas. Human souls are individual due to singular personal characteristics which cannot be reduced to

${ }^{7}$ Ancius M. S. Boethius, Theological Tractates and the Consolation of Philosophy, trans. Hugh F. Steward, Edward K. Rand and Jim Tester (Oxford: The Project Gutenberg, 2004), 33.

${ }^{8}$ See: Saint Thomas Aquinas, Basic Writings, ed. Anton C. Pegis, vol. 2: Man and the Conduct of Life (Cambridge: Hackett Publishing Company, 1997), 688-690.

["Person" signifies what is most perfect in all nature - that is, a subsistent individual of a rational nature. Summa Theologiae I, q. 29, a. 3].

9 See: Richard Swinburne, The Evolution of the Soul (Oxford: Oxford University Press, 2007), 330-335. 
sensory or formal aspects. In this sense, haecceitas goes beyond common nature, and the individual itself is more perfect than the nature that determines its structure as a representative of a species. ${ }^{10}$ John Duns Scotus's conception of haecceitas had a greater impact on modern philosophy than Thomas Aquinas's conception of the integral unity of the soul and the body. ${ }^{11}$ For Descartes, man's individual properties relate to the soul (the mind), which exists independently of the body. The soul determines the identity of the individual and ensures the unity of the sensory perception of the world. Thanks to the soul, a person can connect his or her own external and internal experiences to make them into a whole, into a unique perception of events. The body, on the other hand, is like a machine actuated by life energy that has its source in the activity of the soul. In Descartes's philosophy, a person's mental distinctiveness has its source in the thinking soul (ego cogito), thanks to which man gains the awareness of "I," that is, an individual's volitional and emotional subjectivity. If it is the soul (the mind) that safeguards the subject's mental unity, then it is the soul-and not the body, or the unity of the body and the soul — that safeguards an individual's personal identity, and its singularity and distinctness. Wojtyła did not accept Descartes's conception in the just outlined mind-body problem; he embraced that of Thomas Aquinas and pointed to the psychosomatic unity of the soul and the body. The mentioning of Descartes is not accidental in this context. References to Cartesianism (rather than to Descartes) occur quite often in the context of mind-body debates. In the realm of cognitive sciences, scholars accept the naturalistic thesis that suggests a link between the mind and the brain, and which rejects the Cartesian proposition concerning the substantive difference and separation between the body and the soul. In addition, cognitivists consistently question the existence of a will that is independent of the body, functioning independently of the brain and responsible for a person's free decisions. The mind-body relation constitutes an important issue in attempts to explain the singularity of a person. Cognitivists, such as Daniel Dennett, reject Descartes's dualistic thesis concerning the substantive difference between the mind and the body, but they also disregard the Aristotelian-Thomistic thesis about the psychosomatic unity of the mind and the body in one personal entity, precisely the thesis which Wojtyła found convincing.

But let us turn to the problem of human nature. According to Woltyła, this term denotes everything that is essentially human. However, "nature" and "essence" seem to have different referents. "Nature" does not denote a concrete

${ }^{10}$ See: John Boler, "Transcending the Natural: Duns Scotus on the Two Affections of the Will," American Catholic Philosophical Quarterly no. 67 (1993), 109-126.

${ }^{11}$ In this article it is not possible to discuss in detail the links between the philosophy of John Duns Scotus and modern conceptions of man. See: Reforging the Great Chain of Being, Studies of the History of Modal Theories, ed. Simo Knuuttila, Synthese Historical Library 20 (Dordrechet: Springer Netherlands 1981). 
existing and acting subject. When we speak of human nature, we point to what inheres in a person in a physical sense. We can consider human nature in the abstract, as something detached from concrete individuals, but, in reality, it is always connected with particular entities. Human nature directly indicates what essentially characterizes all people. Moreover, human nature is oriented towards agency, towards dynamism. The first act of dynamism is human nature; from human nature follow all activities. Birth is the initial moment of this dynamism. ${ }^{12}$ The dynamism which presupposes potentiality constitutes a basic aspect of human nature; it is found in the human being's readiness to act. This readiness is pre-given to the person; it has been prepared in its substantive dynamic structure. Human nature does not determine this dynamism in its entirety, but it does accurately determine its moment of change. Human nature manifests itself in the ability to act (modus), but the actions themselves are manifestations of the human being as a distinct person. We are talking here about the kind of agency which allows for a transition from what is owed to human nature to what belongs to the dimension of personal existence. The actions of a person contain agency, which brings to manifestation a particular "I" and allows this "I" to become aware of itself. This means transcending the state of nature in the biological sense, not through the rejection of one's nature, but through its integration with the mind. The entirety of a person is expressed in human experience, where a synthesis takes place, in a person, of the actualizations of those aspects of human nature upon which the person has no influence, with actions that result from the person's choices. An action or a deed (the actus humanus) is a manifestation of an individual's distinct consciousness. As the cause of all its deeds and, moreover, conscious of this status, a person is capable of capturing and describing this moment. The integration of human nature within a person-suppositum - makes it possible to attain and experience the unity of the two aspects: potentiality and actuality.

According to Wojtyła, human nature in its metaphysical sense is man's essence; it constitutes the humanity in man. On the one hand, a person is "individualized" humanity; on the other, a person makes itself present in its actions and hence the integration of human nature and humanity takes place in a person and through a person and involves the integration of all the dynamism which is proper to man. This connection with metaphysical nature does not deprive the person of freedom. Man's potentiality is linked with his nature in situations in which he as the subject discovers "he can do something but does not have to." Wojtyła points to two dimensions of transcendence-vertical and horizontal. The former is basic and finds its expression in free activity, in a person's con-

${ }_{12}$ Karol Wojtyla, The Acting Person, ed. Anna T. Tymieniecka, translated from the Polish by A. Potocki, Analecta Husserliana, vol. X (Dordrecht: D. Reidel Publishing Company, 1979), 126. 
scious efficacy and not just through an [act of] intentionally directing the will or desires towards a goal. Becoming a person means moving from a state of dependency on one's environment to dependency on the "II," that is, on one's self. Being a person involves transcending nature towards the actualization of man's potentiality in personal existence. ${ }^{13}$

In his or her action a person defines himself/herself by self-possession, selfgovernance, self-determination, and self-consciousness. A person is a being that owns oneself; at the same time, it is a being that is exclusively owned by itself. This kind of argumentation presupposes the existence of free will in man, which makes possible the taking of decisions. Thanks to self-determination, man has control over himself as well as power over himself and his actions. A person's freedom manifests itself as a personal attribute which relates to free will and the ability to decide and act freely. ${ }^{14}$

When discussing Wojtyła's conception, we need to take into account the aspect of going beyond (transcending) biological nature. Self-determination allows us to distinguish between dynamism on the level of human nature and dynamism on the level of the person. In the former, there is no self-determination but rather "actualizations," or the type of activity with no influence from the individual will; in the latter, however, we acknowledge the dependence of the will on the activity of a person's own "I." In the dynamism on the level of human nature, the individual is, as it were, owned by the potentiality of its own subject, which determines the direction and the character of the dynamics of personal life. The experience that comes with the discovery that "I am an agent" distinguishes it from the manifestations of the dynamism of man's activity which lack the moment of "I"-agency. ${ }^{15}$ There is a difference here between the one who performs an action and the one who is an action's conscious originator. This latter occurs when a person acts out his or her own choices, rather than being compelled by an instinct or a biological impulse. The justification of the ability to make free choices is important insofar as it constitutes man as a substantially distinct person.

The idea of a conscious and free "I" lies at the foundation of Wojtyła's conception of legal and moral responsibility. A refusal to acknowledge personal agency undermines the essence of that responsibility. A person's independence is constituted, not through its lack of dependence on external factors, but through an unhampered subjection of the will to the directives of reason. Independence is not at issue but the finding of appropriate arguments to support the idea of self-dependence. Freedom manifests itself not through the lifting of

13 Wojtyła, The Acting Person, 131-134.

${ }^{14}$ Karol Wojtyła, The Transcendence of the Person in Action and Man's Self-Teleology, Analecta Husserlina, vol. IX: The Teleologies in Husserlian Phenomenology, ed. Anna T. Tymieniecka (Dordrechet: D. Reidel Publishing Company), 203-212.

15 Wojtyła, The Acting Person, 163-167. 
barriers, but through a person's ability to accept internal and external circumstances and conditions that determine acting. The rationality of a person's moral choices comes from the fact that proper conduct is a consequence of his or her discovery of its righteousness; it does not come from fear of punishment or an expectation of being rewarded by other people. ${ }^{16}$

This brief reconstruction of Karol Wojtyla's conception of personhood has hopefully put into relief the problematics of the person, conscious choice, free will, and the theories of man implied by cognitive studies.

\section{The Person from the Cognitive Perspective}

Philosophical and cognitive models of understanding man differ significantly in their premises and methodological perspectives. Wojtyła accepted realistic principles governing the existence of the human person and was also aware of the benefits of the phenomenological analysis of human consciousness and of man's inner experiences. Wojtyła's conception of personhood represents the tradition of the substantive understanding of the person as an entity that guarantees the continuous identity of the self throughout a person's life. In contradistinction to this position is the a non-substantive one, according to which personal identity depends on the permanence of a person's memory of his or her past states and experiences. According to theorists who represent the non-substantive conception of personhood, while people forget certain past acts or minds modify the events they store, it can become difficult to speak of a person's "permanent identity." As a consequence, changing consciousness is a vehicle for changing personal identity. John Locke, the classic British empiricist, was among the proponents of this theory; Derek Parfit is a contemporary one. Conceptions worked out in the Anglo-Saxon philosophy of the mind support the dynamic theory of the development of the conscious "I" and call into doubt substantive solutions. ${ }^{17}$ In this school of thought, the term "individual entity" is preferred to that of a "person." "18

16 See Immanuel Kant, Groundwork of the Metaphsics of Morals: A German-English Edition, edited and translated by Mary Gregor and Jens Timmermann (Cambridge: Cambridge University Press, 2011), 54-57.

${ }^{17}$ See: John Locke, An Essay Concerning Human Understanding, ed. Roger WoolHouse (London: Publishing Books Ltd., 1997), 472; Derek Parfit, Reasons and Persons (Oxford: Oxford University Press, 1986), 248-252.

${ }^{18}$ One of the interesting exceptions is the metaphysical theory of individual entities put forth by Peter S. Strawson. See his Individuals. An Essay in Desciriptive Mataphisics (London: Methuen \& Co., Ltd., 1987, 1959). Strawson combines metaphysical analyses 
In a general sense, the cognitive sciences are not concerned with man's subjective experiences, but provide descriptions of objective and general phenomena occurring in the human brain. Their main purpose is to explain the process whereby multiple neuronic impulses give rise to an individual human consciousness, in which, at some point, the awareness of a distinct "I" manifests itself. ${ }^{19}$ In a sense, cognitivism brings a broadening of the scope of research represented by the philosophy of the mind which has closer affinities with John Locke's conception of man than with that of Descartes. Thomas Nagel, among other scholars, believed that the individual consciousness of one's "I" (of personhood) is not connected with any additional dimension of human life beyond its biological and social ones. A man is his brain, and what matters most to him is the maximal prolongation of the brain's existence. ${ }^{20}$ This type of belief is called reductionism, and is often accepted by cognitivists.

Daniel Dennett is a brain reductionist who debates Descartes's view on the substantive difference between the spiritual and somatic spheres in man. In his argumentation, Dennett cites research done by neuroscientists Wolf Joachim Singer and Gerhard Roth. Dennett has expressed the view that "the conscious spirit" is an illusion of our thought. A reductionist holds that human mental states can be elucidated in terms of physical-cerebral processes. Dennett claims that the individual consciousness is a postulated, theoretical, cultural, and social fiction which has determined our inner preferences and our general attitudes to the world. ${ }^{21}$ Similar conclusions can be found in the work of other neurologists; for instance, Gerhard Roth regards free will and the awareness of our own distinct "I" as cultural illusion. According to Roth, philosophers are wrong in ascribing to the conscious subject abilities which should be linked exclusively to the activity of the brain. Freedom of the will is the result of an overlapping of neural processes; the brain makes a person predisposed towards survival and adjustment to the conditions of the environment, and not towards making conscious and responsible decisions. ${ }^{22}$

The negation of free will undermines the essence of an agent's responsibility. The advocates of the reductionist position commonly cite experiments conducted by Benjamin Libet and repeated by Evelyn Keller and Heinz Heck-

with the philosophy of language. In his research, he goes beyond reductionist and naturalist approaches.

19 See: David J. Chalmers, The Conscious Mind: In Search of Fundamental Theory (Oxford: Oxford University Press, 1996), 4-5.

${ }^{20}$ See: Thomas Nagel, "The Limits Objectivity," in The Tanner Lectures on Human Values (Oxford: Oxford University, 1979), 78-80.

${ }^{21}$ See: Daniel C. Dennett, Consciousness Explained (London: Penguin Books Ltd., 1993), 237-239.

${ }^{22}$ See: Józef Bremer, Neuronaukowy i potoczny obraz osoby w kognitywistyce (Kraków: Wydawnictwo WAM, 2016), 39-44. 
hausen, and later by Patrick Haggard and Michel Emmer. In a series of experiments, Libet asked participants to concentrate on their willingness to act while observing the position of the clock's hand and to record the time by pressing a button. The researchers observed that the gap between the awareness of the intention to act and the pressing of the button lasted $200 \mathrm{~ms}$, with the margin of error smaller than $50 \mathrm{~ms}$. Libet's experiment showed that conscious decision was preceded by an unconscious activity of the brain. An external observer could see, on the display of his measuring devices, impulses manifesting the activity of the brain before the participant made a conscious decision to act. However, the results obtained in subsequent experiments were less unambiguous. What matters to us are the philosophical conclusions that can be drawn from the experiment.

Citing Libet's experiment, brain reductionists opt for the determinist hypothesis, which allows them to reject the idea of free will and espouse the idea that the will depends on biological and social factors. Among other like-minded scientists, Michael Gazzaniga regarded the conscious "I" as an illusion. In his view, the brains of individual people resemble automata which take decisions by following complex and intricate rules. Moral and legal responsibility are the result of a social contract entered into by brain automata in the context of social debate. ${ }^{23}$ This type of solution is not wholly hostile to the idea of conscious efficacy and self-government advocated by Wojtyła. We have to point out, however, that cognitive studies broaden our knowledge of brain disfunctions, in particular when it comes to cases where we want to discover causes of limited liability in persons with an impaired ability to make independent decisions and to understand complex legal and moral situations. ${ }^{24}$

However, the rejection of radical brain determinism does not need to lead to the acceptance of the opposite theory, or that of voluntarist indeterminism. A reasonable solution seems to lie in the acceptance of moderate determinism, also referred to as emergentizm, or-in more general terms - the emergentist conception of personhood. This position is represented, among other scholars, by Roger W. Sperry and Colwyn Trevarthen, and in Poland by Józef Bremer. According to this conception, the biological structure, having attained a certain

${ }^{23}$ See Michael Gazzaniga, The Law and Neuroscience Project, www.lawandneuroscienceproect.org.

${ }^{24}$ Besides the reductionist position, there is also a non-reductionist one represented by John Eccles, in which the assumption is that the nonmaterial mind influences the functioning of the biological brain. Many processes occur in the brain and only some of them are reflected in cerebral stimulations. Eccles explains the origin of human consciousness by using the principles of quantum mechanics. According to his hypothesis, the mind influences the functioning of the brain by modifying similar stimulations of neurons on the quantum level. This conception has found no confirmation in subsequent empirical studies. See: Karl Popper and John Eccles, The Self and Its Brain. An Argument for Interactionism (London and New York: Routledge, 1977), 355-376. 
level of development and complexity, has caused the human brain to produce new mental and volitional properties (those of the understanding and the will). Thanks to this type of cerebral abilities, man can control his conduct and the processes occurring in the nervous system. In this sense, the conscious mind is capable of self-organization, self-awareness, self-control, and the control of a person's behaviors, and thus of self-dependence. These capabilities are related to the development of language competence, to the building of interpersonal relations, and to the creation of narratives about oneself and linking a self-narrative with narratives shared by the community. On the one hand, a person takes decisions based on intuition, and he or she may not be aware of their causes. On the other, there are conscious, purposeful, and rational actions over which we have a degree of control.

Advocates of the emergentist conception of personhood assume that personal differences have their primary sources in society and culture. Simultaneously, they accept the idea of human free will in its moderate version, a position that can be called compatibilism. According to this idea, the human subject can make choices which are free to a certain degree, biological and social limitations notwithstanding. Sperry and Trevarthen have based their research on free will on stochastic models. Their studies do not explain how the intention to act originates in the brain; they are good at showing the full complexity of the decision-making process and its outcome. They recognize the role of the brain's spontaneous activity, of external signals, and those that can be related to "the will" and individual "beliefs." ${ }^{25}$ It seems that the mind cannot be regarded merely as a function of the biological brain. From the point of view of empirical research, however, it is difficult to study the functioning of the mind as an object disconnected from the brain. Yet it is possible to observe states of the brain and relations occurring between them, and to describe them on the basis of the rules governing human behavior. Still, this mechanistic model will never depict the subjective state of the mind; this is as much to say that the conception of the person as an entity that is conscious and capable of voluntary acceptance of responsibility cannot be inferred from the idea of the body-brain. ${ }^{26}$ The brain constitutes a material basis for mental states, but it does not account for their complexity.

Roger Sperry admits that subjective mental phenomena regulate the movement in nerve cells, which takes place thanks to emergent properties. In this sense, we can say that the mind emerges from the brain; changes occurring in the brain lead to new interactions between neurons, which finally leads to the emergence of a new, distinct quality: the conscious, individual "I." It is

${ }^{25}$ See: Józef Bremer, Neuronaukowy i potoczny obraz osoby w kognitywistyce (Kraków: Wydawnictwo WAM, 2013), 47-52.

26 See: Włodzisław Duch, Czy jesteśmy automatami? Mózgi, wolna wola i odpowiedzialność, 229-230. 
impossible to detect the emergence of individual consciousness on the basis of empirical analysis. We observe the effect of this process, but we do not know how it occurs. ${ }^{27}$ The principles which govern the reconfiguration of the complex elements of the brain system that make possible the emergence of a singular and conscious "I" are for us impossible to elucidate. A suitable material organization within the brain is essential for the emergence of the thought process, but it does not explain everything. This process is more complex and goes beyond biological causes. Experiences related to free will are given to us only from the internal perspective, while the external perspective points to the limitations of free choice.

We know that neurons in the brain react to the stimuli that reach them from the outside world. Large groups of neurons form mesoscopic networks, which in turn make up larger areas that process data supplied by the senses. In this way, the brain builds the sensory image of an object. ${ }^{28}$ There are also emotion and motion maps which allow us to locate the stimuli that enable the control of muscles. We know much less about the higher cognitive abilities, those related to decision making, thinking, reasoning, and planning.

In conclusion, we can state that the emergentist conception of the mind can be reconciled with Karol Wojtyła's dynamic conception of personhood. In both we find premises affirming the psychosomatic unity of body and mind, despite the fact that this unity is construed differently. Woltyła proposes a philosophical and theological conception of personhood supported by phenomenological analyses; in cognitive sciences, knowledge related to man is based on empirical research, subsequently validated by philosophical reflection. Individual consciousness - the consciousness of a person, we may add after Wojtyła - is the product of a dynamic change occurring in man's body and mind. This dynamism is the consequence of a combination of complex structures which condition man's life and development in both their biological and social dimensions. The free will in man does not emerge from independence of biological and social circumstances, but rather from a person's concession to accept them; this autonomy is of course limited, as are the powers of concession. Personal freedom does not mean that man can ignore limitations resulting from the physical structure of the world or from the biological factors responsible for the functioning of the brain.

27 See: Roger Sperry, "A Modified Concept of Consciousness," Psychological Review, vol. 76, no. 6 (1969): 532-536. Józef Bremer arrives at similar conclusions: Bremer, Osoba - fikcja czy rzeczywistość, 362-387.

28 See: Włodzisław Duch, "Czy jesteśmy automatami? Mózgi, wolna wola i odpowiedzialność," in Na ścieżkach neuronauki, ed. Piotr Francuz (Lublin: Wydawnictwo KUL), 219-264. 


\section{Conclusions}

Brain sciences fulfil a very important role in advancing our knowledge about man; their unquestionable achievements cannot be ignored. At present, we are still at an early stage of our exploration of the complex structure of the human mind. Subsequent discoveries may turn out to be ground-breaking, and hence, from the perspective of philosophical anthropology, we need to keep a close watch on the findings that these sciences yield. It is not possible to prove the existence of the person empirically. We can examine bodies, we can analyze the subjective states of human consciousness, and we can study the functioning of man in different various social relations. We can observe the states of the human brain and capture in schemata the operations of the body; however, this mechanistic and biological model is not capable of accounting for the emergence of the consciousness of an individual human being. We may have no direct influence on a great number of cerebral phenomena, but we can modify the course of our thoughts. The conscious "I" is capable of adjusting to the conditions of the environment, but also of altering those conditions.

The sum total of a multiplicity of relations and connections gives shape to the human person, by which we mean the singular and unique individual with an unrepeatable record of inner experiences and reflections: the conscious human "I" capable of making free choices. In this idea of personhood, our belief is grounded in individual value and dignity. In this sense, the conception of personhood constitutes a basis not only for personalist ethics, but for every system of ethics which posits the value of the singularity of human life and individual agency. The premise concerning the singularity of existence and consciousness relates to the principles of self-consciousness, self-determination, and self-possession propagated by Wojtyła. The values of freedom and the value of the person are integrally linked to each other. The negation of freedom, which is a consequence of some cognitive theories, leads to the making void of an individual's autonomy of action. In this case, the prefix "self-" becomes an illusion, and an individual's actions are regarded as resulting from electric impulses in the brain, or from the influence of environmental factors. If we accepted the reductionist premises about man, then logic would compel us to admit that normative ethics is a province of neurocybernetics, by which we understand a theory of controlling and modelling group behavior, or that of social engineering, based on algorithms of socially accepted norms of correct behavior. Regardless of how we evaluate the strength of Woltyła's argumentation in his book The Acting Person, the assumption concerning free will constitutes an essential premise of any ethical theory which accepts the idea of the conscious "I." However, we need to keep up with the developments in the field of cognitive studies, because 
cognitivism provides important contributions to our knowledge of man. The consequences of new discoveries in this field ought to become objects of philosophical, theological, and legal studies.

\section{Bibliography}

Basic Writings of Thomas Aquinas, edited by Anton C. Pegis, vol. 2: Man and the Conduct of Life. Cambridge: Hackett Publishing Company, 1997.

Boethius, Ancius M. S. Theological Trectates and the Consolution of Philosophy. Translated by Hugh. F. Steward, Eedward K. Rand and Jim Tester. Oxford: The Project Gutenberg, 2004.

Bremer, Józef. Osoba - fikcja czy rzeczywistość. Kraków: Wydawnictwo WAM, 2008.

Bremer, Józef. Neoronaukowcy i potoczny obraz osoby w kognitywistyce. Kraków: Wydawnictwo WAM, 2016.

Bremer, Józef. Problem osoby $w$ świetle neuronauk. Czy osoba to jedynie użyteczna metafora? STD 2018, $\mathrm{nr}$ 4, 11-27. https://repozytorium.uwb.edu.pl/jspui/handle/11320/7803.

Boler, John. "Transcending the Natural: Duns Scotus on the Two Affections of the Will." American Catholic Philosophical Quarterly no. 67 (1993), 109-126.

Chalmers, David J., The Conscious Mind: In Search of Fundamental Theory (Oxford: Oxford University Press, 1996).

D'Andradde, Roy. The Development of Cognitive Anthropology. Cambridge, UK: Cambidge University Press, 1995.

Dennett, Daniel C. Consciousness Explained. London: Penguin Books Ltd., 1993.

Duch, Włodzisław. Czy jesteśmy automatami? Mózgi, wolna wola i odpowiedzialność. In Na ścieżkach neuronauki, edited by Piotr Franzuz, 219-264. Lublin: Wydawnictwo KUL, 2010.

Gazzaniga, Michael. The Law and Neuroscience Project. https://www.macfound.org/media/ article pdfs/law and neuroscience 0408.pdf.

Kant, Immanuel. Groundwork of the Metaphsics of Morals: A German-English Edition, edited and translated by Mary Gregor and Jens Timmermann. Cambridge: Cambridge University Press, 2011.

Locke, John. An Essay Concerning Human Understanding, edited by Roger Woolhouse. London Publishing Books Ltd., 1997.

Nagel, Thomas. "The Limits Objectivity." In The Tanner Lectures on Human Values. Oxford: Oxford University Press, 1979.

Pala, Amadeusz. Struktura dynamizmu człowieka-osoby $w$ antropologii adekwatnej Karola Wojtyty. Logos i Ethos nr 1 (47) (2018): 131-151.

Parfit, Darek. Reasons and Persons. Oxford: Clarendon Press, 1986.

Popper, Karl, and Eccles John. The Self and Its Brain. An Argument for Interactionism, 355-376. London and New York: Routledge, 1977.

Reforging the Great Chain of Being, Studies of the History of Modal Theories. Edited by Simo Knuuttila. Synthese Historical Library 20. Dordrechet: Springer Netherlands 1981.

Shihiu, Han, Georg Northoff, Kai Vogeley, E. Bruce Wexler, Shinobu Kitayama, and Michael E. W. Varnum. A Cultural Neuroscience Approach to the Biosocial Nature of the Humane Brain. Annual Review of Psychology, vol. 64 (2013). https://doi.org/10.1146/annurevpsych-071112-054629. 
Strawson, Peter S. Individuals. An Essay in Desciriptive Mataphisics. London: Methuen \& Co., Ltd. 1959.

Sperry, Roger. “A Modified Concept of Consciousness.” Psychological Review, vol. 76, no. 6 (1969): 532-536.

Swinburne, Richard. The Evolution of the Soul. Oxford: Clarendon Press, 2007.

Taylor, Jameson. "Beyond Nature: Karol Wojtyla's Development of the Traditional Definition of Personhood." The Review of Metaphisics, vol. 63, no. 2 (2009): 415-454.

Wojtyła, Karol. "Ocena możliwości zbudowania etyki chrześcijańskiej przy założeniach systemu Maksa Schelera.” In Człowiek i moralność II: Zagadnienie podmiotu moralności, edited by Tadeusz Styczeń, Jerzy W. Gałkowski, Adam Rodziński, and Andrzej Szostek. Lublin: TN KUL.

Wojtyła, Karol. The Acting Person, edited by Anna T. Tymieniecka. Translated from Polish by Andrzej Potocki. Analecta Husserliana, vol. X. Dordrecht: D. Reidel Publishing Company, 1979.

Wojtyła, Karol. "The Transcendence of the Person in Action and Man's Self-Teleology." Analecta Husserlina, vol. IX: The Teleologies in Husserlian Phenomenology, edited by Anna T. Tymieniecka, 203-212. Dordrecht: D. Reidel Publishing Company.

Żegleń, Urszula. „Znaczenie filozofii dla kognitywistyki.” In Przewodnik po kognitywistyce, edited by Józef Bremer, 39-78. Kraków: Wydawnictwo WAM, 2016.

Mariusz Wojewoda

\section{Il concetto di persona nel pensiero di Karol Wojtyła nella prospettiva delle scienze cognitive}

\section{Sommario}

Usiamo il termine di persona, quando vogliamo indicare l'unicità e l'eccezionalità dell'esistenza umana. Il presupposto che l'uomo è una persona è la base per credere nella dignità, nell'efficacia e nella responsabilità di un individuo. La concezione di Wojtyła è stata sviluppata nel contesto delle discussioni teologiche e filosofiche. Se ne è parlato molte volte, ma vale la pena confrontarla con le teorie antropologiche contemporanee derivate dalle scienze cognitive. I rappresentanti di queste scienze di solito si basano su premesse biologiche e sociali. Alcune soluzioni sviluppate nell'ambito delle scienze cognitive portano al riduzionismo cerebrale, in cui una persona viene trattata come un corpo con funzione cerebrale e le sue caratteristiche individuali sono determinate dall'ambiente sociale e culturale. Questa posizione spinge a mettere in discussione l'idea del libero arbitrio e della sostanziale separatezza delle persone. Simultaneamente con la posizione riduzionista si è sviluppata anche una posizione non riduzionista, nota come emergentismo, secondo cui, la mente è un'abilità distinta in una persona che si manifesta a un certo stadio dello sviluppo del cervello. Gli emergentisti argomentano a favore del presupposto dell'unità del corpo e della mente non identica ad esso. Secondo l'autore dell'articolo, questo può essere applicato con successo alla comprensione dinamica della persona sviluppata a metà del XX secolo da Karol Wojtyła.

Parole chiave: Karol Wojtyła, persona, natura umana, libero arbitrio, scienze cognitive 
Mariusz Wojewoda

\title{
Le concept de personne dans la pensée de Karol Wojtyła dans la perspective des sciences cognitives
}

\begin{abstract}
Résumé
Nous utilisons le terme de personne; lorsque nous voulons indiquer l'unicité et l'exceptionnalité de l'existence humaine. L'hypothèse que l'homme est une personne est le fondement pour croire en la dignité, l'efficacité et la responsabilité d'un individu. La conception de Wojtyła a été développée dans un contexte de discussions théologiques et philosophiques. Elle a été maintes fois discutée, mais il vaut la peine de la confronter aux théories anthropologiques contemporaines issues des sciences cognitives. Les représentants de ces sciences s'appuient généralement sur des prémisses biologiques et sociales. Certaines solutions développées au sein des sciences cognitives conduisent au réductionnisme cérébral, dans lequel une personne est traitée comme un corps doté d'une fonction cérébrale, et ses caractéristiques individuelles sont déterminées par l'environnement social et culturel. Cette position conduit à remettre en cause l'idée du libre arbitre et de la séparation substantielle des personnes. Simultanément à la position réductionniste s'est développée une position non réductionniste, connue sous le nom d'émergentisme, selon laquelle, l'esprit est une capacité distincte dans l'homme e qui se manifeste à un certain stade du développement du cerveau. Les émergentistes argumentent pour la thèse de l'unité du corps et de l'esprit qui ne sont pas identiques. Selon l'auteur de l'article, cela peut être appliqué avec succès à la compréhension dynamique de la personne développée au milieu du $\mathrm{XX}^{\mathrm{eme}}$ siècle par Karol Wojtyła.
\end{abstract}

Mots-clés: Karol Wojtyła, personne, nature humaine, libre arbitre, sciences cognitives 